\title{
ABSENTEEISM AS A SOCIAL PHENOMENON: INTERPRETATION FEATURES
}

УДК 316.316.4.324:323.2

DOI https://doi.org/10.32843/2663-

5208.2020.12-1.12

\section{Фоломєєв М.А.}

к.політ.н., доцент кафедри прикладної соціології та соціальних комунікацій Харківський національний університет імені В.Н. Каразіна

Крижанівська В.I.

аспірантка кафредри прикладної соціології та соціальних комунікацій Харківський національний університет імені В.Н. Каразіна
Статтю присвячено аналізу сутності абсентеїзму як соціального френомена в сучасних умовах. У cmammi розглянуто інтерпретації сутності абсентеїзму, що здійснено через дихотомію із френоменом політичної участі, колективної/індивідуальної дії, крізь призму декількох концепцій та концептів, що дало змогу здійснити зважену оцінку абсентеїзму як соціального френомена та уникнути спрощеної та стереотипної, переважно негативної конотації. Представлені інтерпретації сутності абсентеїзму дали змогу окреслити демотивацію до політичної участі, що пов'язано зі ставленням до політики, сприйняттям їі значущості, кризою довіри до політики як соціального інституту, транссрормацією ідентичності (громадянської, політичної тощо), нонконфоормізмом тощо. Розгляд абсентеїзму крізь призму концепції політичного ритуалу демонструє, що абсентеїзм стає показником транссрормації ритуалу легітимації влади, індикатором деритуалізації політичного життя та десакралізації влади, порушенням формування символічної ідентичності, групової приналежності та солідарності. Крізь призму теорії ігор розглянуто сутність абсентеїзму як однієї зі стратегій поведінки гравців у «політичній грі», в якій результат залежить від поведінки всіх гравців. У такому ракурсі абсентеїзм $\epsilon$ протестом проти чинних правил гри чи відмовою від участі у грі, що, відповідно, передбачає зміну правил або вирахування стратегій гравців для того, щоб «політична гра» відбулася. Проблематику абсентеїзму розглянуто крізь призму процесів глобалізації, міграції, модернізації, що окреслює трансформації фрорм легітимації влади, довіри до політичних інститутів, кризу ідентичності та ціннісних трансформацій, які зумовлюють зниження рівня залученості громадян до політичних процесів. Розглянуто появу альтернативних форм політичної участі (співвідношення політичних традицій та політичних інновацій), окреслено потенціал нових форм політичних інтернет-комунікацій щодо зниження рівня абсентеїзму, адже з'являються нові форми політичної участі online.
Ключові слова: абсентеїзм, політична участь, політичний ритуал, політичні традиції, політичні комунікації.

The article is devoted to the analysis of the essence of absenteeism as a social phenomenon in modern conditions. Interpretations of the essence of absenteeism are considered in the article, which are carried out through a dichotomy with the phenomenon of political participation, collective/individual action, through the prism of several theories and concepts, which made it possible to carry out a balanced assessment of absenteeism as a social phenomenon and avoid a simplified and stereotypically, mainly negative connotation. The presented interpretations of the essence of absenteeism permitted to outline demotivation for political participation, which is connected with the attitude to politics, the perception of its significance, the crisis of trust to politics as a social institution, the transformation of identity (civil, political, etc.), non-conformism, etc. The contemplation of absenteeism through the prism of the concept of political ritual shows that absenteeism is an indicator of the transformation of the ritual of legitimizing of power, an indicator of the derationalization of political life and desacralization of power, a contravention of the formation of symbolic identity, group affiliation and solidarity. Through the prism of game theory, the essence of absenteeism is considered as one of the behavior strategy of players in a "political game", in which the result depends on the behavior of all players. The issue of absenteeism is considered through the prism of the processes of globalization, migration, modernization, which determine the transformation of the forms of legitimization of power, trust to the political institutions, the crisis of identity and value transformations that cause a decrease in the level of citizen involvement in political processes. The appearance of alternative forms of political participation (the correlation between political traditions and political innovations) is considered, the potential of new forms of political Internet-communications to reduce absenteeism is determined, as a new forms of political online-participation is appearing. Key words: absenteeism, political participation, political ritual, political communications, political traditions.
Постановка проблеми. Нині політична участь є важливою складовою частиною здійснення демократичного врядування та стрижневим елементом забезпечення функціонування представницької демократії. Однак, коли ми говоримо про політичну участь, треба розуміти, що існує і неучасть, рівень якої нині зростає, що окреслюється терміном «абсентеїзм». Абсентеїзм - ухилення від участі у виборах та від участі у політичних подіях загалом (у більш широкому тлумаченні), апатія та байдужість до соціально-політичних процесів. Це призводить до деформації функціонування демократичних інститутів та хиткості легітимності влади. Переважно склалося спрощене сприйняття абсентеїзму як негативного феномена, одного з прикладів девіантної поведінки, феномена, який підриває основи демократії та демократичного врядування. Проте як політична участь $є$ правом (за сутністю - добровільна участь) та формою вираження підтримки влади (обрання виборних представників чи підтримка певного курсу розвитку держави), так і абсентеїзм є правом 
не підтримувати владу чи вибраний державний курс, пасивним протестом та формою вираження «вотуму недовіри» владі. Тому абсентеїзм можна вважати об'єктивним та закономірним процесом розвитку і функціонування політичної системи, проте необхідно враховувати рівень його коливання, що дає змогу визначити ставлення громадян до політичних інститутів, ступінь напруженості у суспільстві та готовність переходу від пасивного спостереження політичних процесів до радикальних дій щодо їх трансформації. Необхідний відхід від негативного маркування абсентеїзму, зважена оцінка абсентеїзму як соціального феномена з аналізом його причин та наслідків.

Тому у науковому дискурсі є полеміка стосовно оцінки абсентеїзму. Частина науковців вважає абсентеїзм симптомом деформації політичнихтагромадянськихінститутів, індикатором низької політичної культури та передвісником соціальної напруженості внаслідок порушення солідарності та самоізоляції від політичного життя суспільства. 3 іншого боку, абсентеїзм є провісником соціально-політичних трансформацій, адже замість традиційних форм участі у політичному житті можуть з'являтися нові форми політичної участі та нові форми легітимації влади, тобто абсентеїзм $€$ перехідною ланкою до політичних інновацій, елементом розвитку політичної системи через кризу та трансформацію традиційних форм політичної активності.

Відповідно, виникає питання щодо оцінки та сприйняття абсентеїзму, його ролі у політичних процесах та трансформації в умовах глобалізації та в цифрову епоху, що, своєю чергою, трансформує форми політичної участі. Науковий інтерес являє визначення сутності абсентеїзму, аспектів, які його зумовлюють, окреслення того, що лежить в основі абсентеїзму і які загрози несе для функціонування демократії та суспільства.

Аналіз останніх досліджень і публікацій. Проблематиці політичної участі приділяють увагу науковці у різних сферах соціогуманітарного знання - соціології, політичних наук, соціальних комунікацій, права та інших.

Політичну участь та абсентеїзм уперше почали досліджувати в рамках електоральної соціології та електоральних досліджень представники Чиказької школи - Ч. Мерріам та Г. Госснел, надалі цю проблематику крізь призму електоральних процесів та електоральної поведінки досліджували П. Лазарсфельд, Г. Лассуел, С. Верба, Н. Най та ін.

Політичну участь у різних аспектах досліджували різні вчені (П. Бурдьє, Е. Вятр, Р. Даль, Р. Дарендорф, И. Шумпетер та ін.), проте можна виділити дві ключові концепції стосовно інтерпретації сутності політичної участі - демократію участі та концепцію демо- кратичного елітизму. Прихильники першої концепції (К. Макферсон, К. Пейтман, Б. Барбер, П. Бахрах, Ф. Нашольд та ін.) обґрунтовують необхідність активного залучення громадян до політичних процесів як стрижневої характеристики демократичного врядування, а також наділення громадян повноваженнями контролю за втіленням прийнятих рішень, до того ж це знижує імовірність «тиранії меншості» (еліти). Послідовники елітаристської концепції (Й. Шумпетер, Дж. Сарторі, Р. Берельсон, У. Корнхаузер, К. Мангейм, Дж. Рекс, Р. Мілібанд та ін.) виступають за обмежену участь громадян у політичному житті, що пояснюється низьким рівнем компетенцій та освіченості громадян, ірраціональністю дій громадян під дією різних факторів.

Серед сучасних соціологічних теорій науковий інтерес являють концепції американського соціолога Д. Халфмана (теорія інституційної політики) та італійського соціолога та політолога Д. Делла Порти (теорія партисипаторної демократії та концепція політичного консьюмеризму), які окреслюють нові концептуальні рамки для аналізу політичної участі. Концепція політичного консьюмеризму дає можливість аналізувати політичну участь як елемент політичного споживання та демонстраційної поведінки, а також визначати фактори, які впливають на неї (групова приналежність, демонстрація певного образу життя та стилю поведінки, гедонізм тощо). Також Д. Делла Порта приділяє увагу особливостям виникнення соціальних рухів та її складникам (формуванню ідентичності, солідарності, колективних дій), що також стосується і політичної участі [13]. Американський соціолог Д. Халфман концентрує увагу на аналізі політичного контексту, описуючи структурні елементи функціонування політичної системи, що створює сприятливі чи ні умови для залученості громадян у політичні процеси, а також розглядає інструменти мобілізації громадян до соціальних рухів, що можна застосовувати і для політичних процесів (наприклад, гротеск як «естетична зброя») [14]. Більш детально особливості застосування зазначених концепцій до аналізу політичної участі розглянуто у роботі «Політична участь та мотивація до неї: евристичний потенціал соціологічних концепцій Донателли Делла Порти і Дрю Халфмана (порівняльна характеристика)» [7].

Хоча абсентеїзм тісно пов' язаний із політичною участю, проте цій проблематиці приділено значно менше уваги науковців, дослідження та напрацювання стосуються переважно причин абсентеїзму.

Проте у західній науці можна виділити 3 підходи до трактування сутності абсентеїзму. У рамках першого підходу абсентеїзм трактується з точки зору теорії раціональ- 
ної дії та розрахунку голосування (А. Даунс), другий підхід трактує абсентеїзм як вид девіантної поведінки (К. Кон, Р. Метрон, які розглядали абсентеїзм як нонконформне та абберантне відхилення), в рамках третього підходу абсентеїзм інтерпретується як показник, який свідчить про стабільність соціальної системи, адже високий рівень активності громадян не свідчить про стабільність соціальної системи, що пов'язано з якістю голосування, освіченістю, рівнем політичної культури тощо (Р. Вілсон, Д. Рісман, С. Хантінгтон, Г. Алмонд, С. Верба, Р. Роуз).

Серед українських соціологів $€$. Головаха звертає увагу на менталітет байдужості, a I. Бекешкіна - на психологію конформізму, що лежить в основі абсентеїзму і характерна для пострадянських країн.

У науковому дискурсі здебільшого розглядають причини абсентеїзму та наслідки, переважно без поглибленого аналізу особливостей трактування сутності цього феномена. Саме цьому аспекту і буде присвячена ця стаття.

Постановка завдання. Метою цієї статті $€$ аналіз сутності абсентеїзму як соціального феномена в сучасних умовах.

Виклад основного матеріалу дослідження. У той момент, коли демократичні права стали загальними та закріпленими, політична участь стала невід'ємним правом і перейшла зі сфери обов'язку до сфери вільного вибору (користуватися своїми правами чи ні). Так, нині $є$ низка країн, де участь у вибоpax $\epsilon$ конституційним обов'язком громадян і ухиляння від участі у виборах (абсентеїзм) передбачає накладання санкцій - Аргентина, Австралія, Бразилія, Кіпр, Еквадор, Ліхтенштейн та ін., загалом 12 держав. Ще у 13 країнах політична участь $€$ обов'язковою (Бельгія, Болівія, Коста-Ріка, Конго, Домініканська Республіка та ін.), але за неучасть санкції не застосовуються. Проте у більшості держав політична участь $€$ конституційним правом громадян, а неучасть ніяк юридично не відображається, тобто перебуває у сфері особистого вибору та відповідальності. Нині можемо спостерігати поступове збільшення частки тих, хто апатично ставиться до соціально-політичного життя та уникає участі у ньому. Це пов'язано із трансформацією сприйняття політичної участі. У період обмеженого доступу, можливості голосування лише для «обраних» (відповідно до статі, кольору шкіри, статусу тощо) та першого запровадження загального рівного виборчого права політична участь сприймалася як привілей, проте поступово стала буденністю та усталеною практикою демократичного врядування. Тому абсентеїзм стає показником усвідомленої відмови від політичної участі як привілею, зникнення сприйняття привілейованості політичної участі, зниження її значущості та цінності для індивіда. Можливо, така апатія та байдужість пов'язані із недостатнім рівнем політичної культури та сприйняттям індивідів себе як суб'єктів політичного процесу (нерозуміння значення політики для суспільного життя, значущості активного громадянства та залученості громадян до демократичного врядування).

Для розуміння сутності та специфіки абсентеїзму варто співвіднести його зі сприйняттям сутності політичної участі. У суб'єктивному сприйнятті політичну участь можна інтерпретувати у різних аспектах, зокрема, як:

- обов'язок: юридичний обов'язок громадянина брати участь у виборах представників влади, обов'язок громадянина перед державою для забезпечення її демократичного функціонування;

- моральне зобов'язання: зобов'язання брати участь у колективному прийнятті рішень для досягнення загального блага, моральний обов'язок громадянина перед іншими представниками громадянського суспільства;

- право: демократичне право висловлювати свою політичну позицію, вибирати представників для керування країною тощо;

- необхідність: політична активність через моральні, етичні, релігійні чи інші переконання;

- можливість: наявність сприятливих умов для впливу на політику і прийняття політичних рішень;

- благо: загальне, колективне чи індивідуальне благо, яке $є$ показником демократичності та загальної рівності, що дає рівні можливості для висловлення своєї політичної та громадянської позиції;

- цінність: цінність політичної участі як можливості самореалізації, самовираження відповідно до цінностей і світогляду;

- публічна демонстративність: демонстрація своєї активної позиції та участі у політичних процесах держави;

- традиція: усталені зразки поведінки щодо відтворення політичних відносин, які передаються із покоління в покоління; політичні традиції можуть відтворюватися на макрорівні (на рівні держави), мезорівні (на рівні різних соціальних інститутів), мікрорівні (традиції політичної участі, які склалися у сім'ї);

- ритуал: стандартизоване повторення політично значущих дій, ідеологічно (міфологічно) та символічно санкціонованих для підтвердження і відтворення соціально-політичного порядку;

- один 3 інструментів конструювання політичної нації (шляхом колективних та символічних дій);

- один з інструментів формування громадянської ідентичності: ідентифікація з групою, окреслення групової приналежності та солідарності; 
- привілей: політична участь як «обмежена можливість», яка дуже цінується, оскільки має певні обмеження (наприклад, тільки громадяни країни мають право брати участь у виборах або тільки ті, хто має прописку, що ускладнює політичну участь тих, хто є вимушеними переселенцями);

- конформний тип політичної поведінки: поведінка «як усі», «так прийнято».

Якщо політичну участь інтерпретувати як політичну можливість, то абсентеїзм можна вважати «втраченою можливістю» (втрачені можливості продемонструвати своє волевиявлення, вплинути на вибір влади, курс майбутнього розвитку держави тощо). Якщо політичну участь інтерпретувати, за Х. Макклонксі, як почуття залученості та загалом процес залученості, то абсентеїзм можна визначити як відстороненість та процес відчуження від політики та прийняття політичних рішень.

Різне сприйняття політичної участі визначає відповідне ставлення до проблеми абсентеїзму, аналізу його сутності та оцінки. Відповідно, абсентеїзм можна інтерпретувати як:

- ухилення від виконання своїх обов'язків: ухилення від виконання громадянських обов'язків, особливо за умови обов'язкової участі у виборах;

- байдужість до політичних процесів: втрата моральної відповідальності за ті процеси, що відбуваються у державі;

- артикуляція власної позиції через мовчання - «пасивний протест»: демонстрація того, що політики порушують неактуальні проблеми на порядку денному;

- знецінення політики як сфери самореалізації людини: абсентеїзм як індикатор зниження значущості політики для індивіда;

- публічна демонстративність: абсентеїзм як пасивний протест внаслідок небажання легітимізувати владу і т.п.;

- відмова від громадянської чи політичної ідентифікації: відсутність формування групової приналежності та ідентифікації із групою на основі політичних факторів, що є перешкодою для утворення політичної нації;

- право: право брати чи не брати участь у політичних процесах;

- нонконформна поведінка: відмова від участі у політичних подіях «як усі» або тому що «так прийнято»;

- свобода - свобода вибору та свобода волі (свобода участі у суспільних та політичних процесах, свобода вибору формату підтримки влади чи, навпаки, вираження своєї політичної позиції через ухилення від участі у політичних процесах).

Політичну участь та абсентеїзм можна розглядати крізь призму політичного ритуалу. Політична участь як комплекс дій щодо виборів представників влади та впливу на формування державної політики (прямо чи опосередковано) є певною усталеною послідовністю символічних дій, порядком дій для обрання представників влади. Це, зокрема, символічна дія для легітимації влади, що передбачає:

- групову взаємодію та формування певної солідарності для здійснення цього ритуалу (забезпечення процедури проведення виборів та сама участь у них);

- встановлення певного емоційного зв'язку між його учасниками (згода, моральна єдність або, навпаки, протестні настрої тощо);

- концентрацію уваги на одному об'єкті або цільовій дії, тобто формування взаємного фокусу уваги.

у такому ракурсі політичну участь можна розглянути крізь призму теорії ритуалів взаємодії, або теорії інтерактивних ритуалів (за Р. Коллінзом). У рамках цієї теорії участь у виборах являє собою певний ритуал, що передбачає формування почуття спільності та приналежності до групи (почуття солідарності), де ключовими складниками для виникнення почуття солідарності є висока частота взаємодій, зосередження уваги на групі і загальні емоції. Тобто ритуали взаємодії можна вважати соціальною технологією з формування груп солідарності. У такому ракурсі вибори являють собою ритуали солідарності, які генерують сильну емоційну прихильність і підтримку символічних вірувань, “Священних» для кожної окремої групи [5, с. 463], що проявляється у солідарності із групою (референтною групою, групою однодумців, демонстрацією своєї громадянської позиції) або солідарності із політичної силою (прихильність певній політичній силі або, наприклад, голосування на певного лідера навіть за умов впевненості, що його очікує поразка). Абсентеїзм, відповідно, являє собою процес деритуалізації, що призводить до відсутності умов (політичного контексту) для формування почуття спільності та групової приналежності, порушує групову солідарність, перешкоджає формуванню груп солідарності на основі емоційного зв'язку та спільних символічних вірувань та дій.

Соціологи розглядали ритуали у декількох аспектах. Е. Дюркгейм визначав ритуали як конфігурацію людей, які концентруютьсвоїтіла, увагу та емоції певним чином [6, с. 233]. Продовжуючи традицію Е. Дюркгейма, У. Л. Уорнер звертав увагу на те, що важливим елементом ритуалу $\epsilon$ церемонії, завдяки яким збирається співтовариство і з'являється символічна ідентичність, встановлюються узи моральної солідарності [6, с. 228]. Прикладом таких ритуальних церемоній є будь-які патріотичні церемонії як ритуальні інструменти класового панування, адже вони підкреслюють групову єдність та імпліцитно надають легітимність тому класу, який очолює ритуали і формує їх 
культурні артефакти. У такому ракурсі вибори (сам день проведення виборів) можна вважати церемонією легітимації влади шляхом проведення ритуалу обрання виборних представників. Особлива ритуальність такої дії характерна для авторитарних держав, де вибори мають лише «церемоніальний» характер, ілюзію виборів та демократичності, що, наприклад, характерно для Північної Кореї, коли на парламентських виборах у 2019 році явка склала 99,99\%, а списки у бюлетенях були фактично безальтернативними. Відповідно, абсентеїзм являє собою деконструкцію ідентичності, руйнування моральної солідарності та групової єдності, нівелювання патріотичних церемоній та підрив легітимності влади через нівелювання ритуальності процедури ії̈ легітимації.

Динамічні ритуали та ритуали солідарності описував американський соціолог І. Гофман, розглядаючи їх як вистави, які потребують певних ресурсів (символічних та культурних), матеріальних якостей і культурних навичок, а також мають важливі соціальні наслідки - створюють ідеальні образи самої людини, встановлюють соціальні зв'язки, які контролюють інших. Ці ритуали утримують суспільство разом, що реалізується через стратифікацію: «Ритуали - це знаряддя, які стверджують і перегруповують класову структуру» [6, с. 232]. На думку І. Гофмана, повсякденні ритуали створюють Я, тобто формують ідентичність, а також забезпечують встановлення контактів, соціальних зв'язків. У такому контексті абсентеїзм як процес деритуалізації сприяє деформації ідентичності та формування Я, обмежує розширення мережі соціальних зв'язків.

Американський соціолог Р. Коллінз використовує поняття «мережа ритуальних взаємодій» для демонстрації, як мікроінтеракції складаються в класову структуру сучасного суспільства [6, с. 247]. Ритуали взаємодії створюють культури різних соціальних класів (мова, особливості поведінки, культурний та символічний капітал, світогляд тощо). Мережі, що виникають з таких повторюваних ритуальних взаємодій, становлять реальність більших структур, що складаються у стратифікацію. Це проявляється, наприклад, у ритуалах влади. Так, віддача і прийом розпоряджень - це ритуал, який породжує класи, які приймають розпорядження, і класи, які їх надають, і їх символічні погляди відповідно. Відповідно, певні напрями емоцій і уваги людей конституюють ритуали, які ведуть до узів членства в суспільстві/певних групах і формування символів, які їх представляють. Формуються «колективні репрезентації», які визначають напрями взаємодії індивідів та утримують від інших. Це можна застосувати для характеристики процесу участі у виборах, а також абсентеїзму.
Отже, участь у виборах як ритуал являє собою формування певної ідентичності (громадянської, політичної, регіональної тощо), окреслює кордони солідарності 3 певною групою та відповідну емоційну прив'язку, публічну демонстрацію своєї політичної позиції та групової приналежності. Формується певна традиційність та ритуальність участі у виборах (нерефлексована участь, оскільки «так прийнято», «так було завжди»). Абсентеїзм, своєю чергою, є показником деритуалізації соціальної взаємодії, трансформації ритуалу легітимації влади. Зникає солідарність щодо участі у виборах представників влади, що $€$ показником втрати значущості політики для частини громадян, деритуалізації повсякденного життя та трансформації усталених форм політичної участі. Також абсентеїзм стає індикатором десакралізації влади. Якщо розглядати сакральність як простір особливої концентрації уваги, то абсентеїзм - процес десакралізації політики, зменшення уваги до політики та обрання представників влади, зниження значущості власної участі у політичних процесах, знецінення політики як такої. Також абсентеїзм руйнує кордони солідарності із групою та основи громадянської ідентичності (основи політичної нації у разі відчуження індивіда від будь-яких форм участі у політичному житті суспільства).

Політичну участь та абсентеїзм можна розглядати крізь призму теорії ігор. Теорію ігор, зокрема, розглядають як математичний метод вивчення оптимальних рішень у рамках побудови стратегій і тактик у т.зв. «ігрових ситуаціях», коли є декілька гравців і результат гри залежить від їх вибору [12]. I хоча це математична модель, проте її можна застосувати і в гуманітарних науках для визначення стратегії поведінки учасників у різних соціально-політичних процесах, зокрема щодо політичної участі та абсентеїзму. Крізь призму теорії ігор вибори являють собою «політичну гру», яка має такі складники, як:

- певна кількість гравців: електорат, різні електоральні групи;

- невизначеність поведінки учасників, оскільки кожний $з$ них володіє декількома варіантами дій (взяти участь у виборах чи ні, зіпсувати бюлетень, проголосувати проти всіх тощо);

- розбіжність інтересів учасників: конфлікт інтересів, що може стосуватися як вибору кандидатів, так і ставлення до виборів та влади - бажання чи небажання легітимізувати владу;

- взаємна пов'язаність поведінки учасників: результат залежить від двох сторін - наприклад, за мажоритарної виборчої системи абсолютна більшість виборів будуть вважатися дійсними (кандидат буде обраним), 
якщо участь у них взяли $50 \%+1$, тобто результат виборів залежить ще й від кількості тих, хто не з'явився на вибори;

- наявність правил поведінки, які знають усі учасники: процедура виборів та їх технічні особливості, правила участі у виборах (громадянство, вік та ін.), вид виборчої системи та її різновиди, обов'язковість участі у виборах чи ні тощо).

У такому контексті політична участь являє собою деяку «політичну гру» за встановленими правилами, результат якої - обрання виборних представників чи спільне прийняття суспільно важливих рішень (шляхом референдуму), тоді як абсентеїзм - відмова від встановлених правил гри чи навіть відмова від участі у грі, що може призвести не лише до простого зменшення кількості учасників гри, але і до неможливості здійснення цієї гри (наприклад, за умови необхідності 50\% +1 голосу), зміни правил гри в умовах зростаючої кризи та конфлікту інтересів (наприклад, зміна типу виборчої системи з абсолютної більшості на відносну більшість, мажоритарної виборчої системи на пропорційну), неприйняття результатів гри (виборів представників влади) тими, хто не брав участь у грі тощо. В такому разі чи можна вважати абсентеїзм загрозою «політичній грі»? Ми вважаємо, що це один із варіантів поведінки «гравців», яку необхідно враховувати, розраховувати коливання його рівня для того, щоб гра відбулася і був досягнутий «рівноважний результат» (з урахуванням ймовірності певного \% участі громадян у виборах).

Отже, теорія ігор окреслює новий ракурс для дослідження політичної участі та абсентеїзму, надає нові грані для інтерпретації сутності абсентеїзму як відмови від політичної гри, незадоволеності правилами гри чи суб'єктами, які беруть участь у грі або її модерують. Відповідно, крізь призму теорії ігор науковий інтерес являє дослідження коливання рівня абсентеїзму та його вплив на здійснення гри, чому сприяє, зокрема, проведення соціологічних опитувань та дослідження електоральної ситуації напередодні проведення виборів.

Політичну участь та абсентеїзм можна розглядати крізь призму концепту довіри як основи виникнення та існування соціальних взаємозв'язків. Політична участь (активна залученість громадян до політичних процесів, виборів, референдумів тощо) $є$ показником довіри до політики як соціального інституту: чим вищий рівень довіри до влади, тим вищий рівень політичної участі (як показник підтримки влади та згоди її легітимізувати). Абсентеїзм $€$ показником низького рівня довіри до політики. Так, за останніми соціологічними дослідженнями, проведеними Інститутом соціології НАН України, 48,8\% опитаних вважають, що серед наявних в Україні політичних партій та рухів немає таких, яким можна довірити владу, 49,3\% вважають, що немає політичних лідерів, які здатні ефективно керувати країною [10, с. 421]. Відповідно, таке ставлення призводить і до викривленого сприйняття індивідом себе як суб'єкта політичних процесів, зниження політичної активності, зняття з себе громадських зобов'язань щодо легітимації влади тих, до кого немає довіри. Це стосується і досить низької явки на виборах Президента України-2019 - 37,2\% українців не взяли участь у виборах [2], а також на виборах до Верховної Ради України-2019 - 50,2\% не взяли участь у виборах [1], на проміжних вибоpax в ОВО № 179 на вибори не прийшло 72,6\% виборців [9]. Така ситуація - індикатор деформації інституту виборів та провісник необхідності його модернізації.

Отже, фіксація високого рівня абсентеїзму або поступового зниження рівня політичної участі є індикатором виникаючої проблеми довіри у суспільстві, зміни ставлення до політики як соціального інституту та політичних лідерів, що також актуалізує проблему легітимації, що може виникнути внаслідок кризи довіри.

Політичну участь та абсентеїзм можна розглядати крізь призму дихотомії колективної/ індивідуальної соціальної дії. Якщо політична участь передбачає формування групової солідарності, що може бути як на мікро-, так і на макрорівні, то відмова від участі - це особиста позиція, яка може сформуватися на основі особистих переконань та ставлення до політики/ політиків або під впливом малої соціальної групи (сім'я, друзі, колектив тощо). Абсентеїзм - це порушення колективних дій та формування індивідуальної траєкторії політичної дії в умовах індивідуалізованого суспільства, чи це нова форма колективної дії, що приймає форму пасивного протесту як вотум недовіри чинній владі та небажання її легітимізувати?

Отже, в умовах індивідуалізованого суспільства абсентеїзм можна розглядати як індивідуалізований тип політичної поведінки, що, по суті, є наслідком відходу від традиціоналізму та деритуалізації політичного життя, індикатором порушення колективних дій та традиційних колективних форм соціальної взаємодії.

Політичну участь та абсентеїзм можна розглядати крізь призму концепту стереотипів, які транслюються різними каналами комунікації та створюють фрейми сприйняття політики, що, зокрема, зумовлює і власну залученість до політичних процесів.

Абсентеїзм може виникати на різних підставах: стереотипи щодо політики та політиків, які транслюються через ЗМІ, освіта, цінності, вплив батьків, вплив референтної групи тощо. 
Чому відбувається втрата довіри до політики як до соціального інституту? Як зазначав Е. Гідденс, «довіра до систем приймає форму безособистісних зобов'язань, у яких віра підтримується шляхом функціонування знання, у якому проста людина здебільшого не розбирається» [3, с. 217]. Це стосується політичної культури та громадянської освіти, оскільки, наприклад, більшість молоді не знає свої політичні права, не розбирається у повноваженнях президента або прем'єр-міністра тощо. Відповідно, відсутня громадянська відповідальність та розуміння громадянського обов'язку, формується викривлене сприйняття політики, до того ж люди без достатнього рівня громадянської освіти легко стають жертвами маніпулювання та популізму.

Отже, внаслідок трансляції стереотипів формується спрощене уявлення про політику та значущість залученості до політичних процесів. Це стосується і освіти, оскільки, наприклад, саме у школах закладаються основи громадянської освіти та громадянського активізму. Так, сприятливими умовами для розуміння значення політики та власної політичної участі $€$ наявність шкільного самоврядування та проведення виборів президента школи, що $є$ за сутністю мікромоделлю демократичного врядування, яке відбувається на рівні держави. Відповідно, наявність таких позитивних практик у школах сприяє виникненню активного громадянства та громадянського виховання, і гіпотетично здатна знизити рівень абсентеїзму серед певної категорії громадян, сформувати відповідальне ставлення до участі та прийнятті політичних рішень тощо.

Політичну участь та абсентеїзм можна розглядати крізь призму теорії глобалізації. Ще Е. Гідденс описував «парадокс демократії», який проявляється у тому, що демократія нині поширюється по всьому світу, проте водночас у зрілих демократичних державах зростає розчарованість у демократичних процеcax, зменшується рівень довіри до політики та кількість людей, які беруть участь у виборах [4, с. 86]. Зростає рівень абсентеїзму, змінюється ставлення до політики та її значущість (втрата довіри до політики як соціального інституту), з'являються нові форми легітимації влади та нові форми політичної участі (феномен «електронної демократії» тощо). Так, вибори є традиційною формою легітимації влади, проте в умовах динамізму, космополітизму, втрати сталості та визначеності, високого рівня міграції вони втрачають свою значущість. Е. Гідденс вважає, що нині відбувається «відмирання» старих форм легітимації влади, які стають неефективними в умовах глобалізації [3]. Р. Інглхарт зазначав, що прості форми політичної участі (вибори, голосування) втрачають свою дієвість, повинні бути замінені на більш складні механізми забезпечення політичної участі. Проте, говорячи про «відмирання» традиційних форм легітимації влади, ні Е. Гідденс, ні Р. Інглхарт не описують альтернативні форми, які сприятимуть більшій залученості громадян до виборів. Так, е-голосування - це лише диджіталізований формат традиційних виборів, він не здатний подолати ті причини, які лежать в основі абсентеїзму (якщо це розчарованість у політиці, іï знецінення, зневіра у можливості вплинути на політичні процеси у суспільстві та ін., то форма голосування - електронна чи паперова - не змінить ставлення громадян до самого процесу). Відповідно, проблема постає у визначенні того, що лежить в основі абсентеїзму, які загрози це несе для функціонування демократії та яким чином ці загрози можна нівелювати.

Також процеси глобалізації, інтерналізації та інформатизації викликають кризу ідентичності (особистісної, громадянської, національної, державної). Це також $€$ фактором впливу на рівень участі у політичному житті, оскільки трансформує самосприйняття особистості, цінності, життєві орієнтири. Якщо індивід перестає відчувати себе повноцінним громадянином своєї держави, відмежовується від неї, то втрачає мотивацію до участі у політичному та громадському житті, громадянську відповідальність та обов'язки. Або у людини формуються інші життєві цінності та орієнтири, до яких політика не належить, тому вона зникає з її фокуса уваги. Тому можна зазначити, що абсентеїзм $€$ відмовою від символічної ідентичності, від ідентифікації себе із певною політичною спільнотою.

3 іншого боку, громадянська ідентичність буде мотивувати брати участь у виборах на національному та місцевому рівнях, проте можлива ситуація, коли людина не вірить у спроможність вплинути на політику на макрорівні, проте бере участь у місцевих виборах (адже бачить результати дії влади на місцях), участь у виборах представників місцевого самоврядування тощо. Це показник існування регіональної ідентичності. Чи можна у такому разі говорити про абсентеїзм і як його оцінювати?

Отже, в умовах глобалізації та інформатизації трансформуються форми політичної участі та легітимації влади (е-голосування один з альтернативних варіантів), а абсентеїзм може бути зумовлений як перехідним етапом від традиційних до нових форм політичної участі, так і кризою ідентичності та ціннісними трансформаціями, що характерне для сучасного суспільства.

Політичну участь та абсентеїзм можна розглядати крізь призму концепту міграції. Міграційні процеси тісно пов'язані з глобалізацією і також зумовлюють високий рівень абсентеїзму, особливо серед молоді. За досліджен- 
ням KMIC 2018 р., 7\% українців хочуть виїхати з України за кордон (збираються найближчим часом) [8]. Відповідно, якщо молода людина, наприклад, після завершення навчання планує виїхати за кордон (стажування, тимчасова робота або на постійне місце проживання), то в неї немає мотивації до участі у політичних процесах у країні, яку вона збирається змінити. Локальна залученість трансформується у взаємодію на відстані (за термінологією Е. Гідденса), що вилучає із фокусу уваги політику, оскільки не несе цінності для індивіда, не відповідає потребам та інтересам, що є закономірним та об'єктивним процесом.

Політична участь трансформується і завдяки модернізації інформаційних технологій, які укорінюються у повсякденному житті. Так, вірогідно, традиційні форми політичної участі замінюються або доповнюються альтернативними, які реалізовуються шляхом інтернет-комунікацій. Так, можливо, нині індивіду досить висловити свою політичну позицію шляхом обговорення у групах, коментування публікацій чи участі в онлайн-опитуваннях, що замінює традиційну участь у виборах (проте це більш характерно для молоді). Тут варто говорити про співвідношення політичних традицій та політичних інновацій [11], перспективи та роль політичних інтернет-комунікацій та технологій: наскільки застосування інтернет-технологій сприяє залученості громадян до політичної участі? чи з'являються нові чи альтернативні форми політичної активності і як вони трансформують політичну участь оффлайн? чи зможе е-голосування сприяти активізації політичної участі, особливо серед молоді? Це ті питання, які нині потребують пошуку відповіді, особливо в умовах інформаційного суспільства.

Отже, процеси глобалізації, міграції, інформатизації, модернізації, диджіталізації впливають на абсентеїзм, що пов'язано з кризою ідентичності, трансформацією цінностей та життєвих орієнтирів, а також появою нових комунікативних технологій, які сприяють виникненню нових форм політичної участі, у т.ч. у вебпросторі.

Висновки з проведеного дослідження. Таким чином, у статті представлені інтерпретації сутності абсентеїзму крізь призму дихотомії політична участь/абсентеїзм, колективний/індивідуальний, а також крізь призму концепції політичного ритуалу, теорії ігор, теорії глобалізації, концептів довіри, стереотипів та міграції.

Розуміння сутності абсентеїзму у співвідношенні із розумінням політичної участі дає змогу окреслити мотивацію та демотивацію до політичної участі. Зокрема, мотивація до політичної участі зумовлена довірою до політики як соціального інституту та політичних лідерів (згода висловити підтримку владі в «обмін» на представлення та захист своїх інтересів), сприйняттям політики та політичної участі як цінності, активною громадською позицією, можливістю реалізації своїх громадянських прав, звичкою та традицією брати участь у виборах, конформізмом тощо. Своєю чергою демотивація до політичної участі зумовлена знеціненням політики для індивіда, розчарованістю у функціонуючій політичній системі, недовірою до політиків та інституту виборів (політика - «брудна справа», а вибори - «фікція»), вираженням своєї громадянської позиції (абсентеїзм як форма бойкоту, «вотум недовіри» владі), зневірою у власній спроможності впливати на політику, традиціями політичної неучасті, яка склалася у сім'ї або під впливом друзів, нонконформізмом (небажання бути та діяти «як усі») тощо.

Розглянуті концепції щодо інтерпретації політичної участі та абсентеїзму відкривають нові аспекти розуміння не тільки того, що лежить в основі абсентеїзму, але і до яких соціокультурних наслідків він може призвести. Так, абсентеїзм крізь призму концепції політичного ритуалу виступає індикатором деритуалізації політичного життя та десакралізації влади, трансформації традиційних форм політичної участі та легітимації влади, порушення основ формування символічної ідентичності, групової приналежності та моральної солідарності. Крізь призму теорії ігор абсентеїзм може бути інтерпретований як один з варіантів поведінки гравців «політичної ігри», що може призвести до неможливості здійснення гри, зміни правил, зміни поведінки інших гравців або переструктурування кола гравців.

Також аналіз абсентеїзму крізь призму глобалізації, міграційних процесів, інформатизації та модернізації дав змогу окреслити аспекти, які зумовлюють абсентеїзм. До них можна віднести кризу ідентичності в умовах глобалізації, кризу довіри до політичних інститутів, трансформацію цінностей та життєвого світогляду, трансформацію традиційних форм політичної участі та появу нових, наприклад, «електронної демократії» та е-голосування, диджіталізації та політичних інтернет-комунікацій, які створюють альтернативний комунікативний простір та нові можливості для політичної участі online. $Є$ гіпотетичне припущення, що нові технологічні можливості, зокрема, е-голосування, здатні сприяти активізації залученості громадян до політичних процесів. Проте здебільшого це зміна формату, але не сутності, оскільки в основі абсентеїзму лежить криза довіри до політичних інститутів, розчарованість у чинній політичній системі, «пасивний протест» проти влади, небажання ії легітимізувати тощо, тому нові технології не змінять ставлення до самого процесу. 
Відповідно, аналіз сутності абсентеїзму дає змогу здійснити його зважену оцінку як соціального феномена, уникнути спрощеної та стереотипної, переважно негативної конотації, визначити не тільки причини, які зумовлюють виникнення абсентеїзму, але і загрози, які несе абсентеїзм для політичної системи та суспільства, та можливості нівелювання цих загроз (доцільність та комунікативні технології нівелювання). Саме це є перспективним напрямом подальшого дослідження проблематики абсентеїзму.

1. Вибори народних депутатів України-2019. URL: https://www.cvk.gov.ua/pls/vnd2019/ wp095_2pt001f01 $=919$ pt049f01 $=2 . \mathrm{html}$.

2. Вибори Президента України-2019. Явка виборців. URL: https://www.cvk.gov.ua/pls/vp2019/ wp063pt001f01=719.html.

3. Гидденс Э. Последствия современности. Москва : Праксис, 2011. 343 с.

4. Гидденс Э. Ускользающий мир: как глобализация меняет нашу жизнь. Москва: Весь мир, 2004. 120 с.

5. Коллинз Р. Социологическая интуиция: Введение в неочевидную социологию. Личностно-ориентированная социология / пер. с англ. В.Ф. Анурина. Москва : Академический Проект, 2004. 608 с.

6. Коллинз Р. Четыре социологические традиции / пер. с англ. В. Россмана. Москва : Издательский дом «Территория будущего», 2009. 320 c.
7. Крижанівська В.І. Політична участь та мотивація до неї: евристичний потенціал соціологічних концепцій Донателли Делла Порти і Дрю Халфмана (порівняльна характеристика). Український соціологічний журнал. Харків, 2019. № 22. С. 36-51.

8. Міграційні настрої населення України у квітні 2018 року. URL: https://www.kiis.com.ua/?lang=ukr\& cat=reports\&id=765\&page $=1$.

9. Проміжні вибори в ОВО № 179 15.03.2020. URL: https://www.cvk.gov.ua/pls/vnd2019/ wp095_2pt001f01=920pt049f01=2.html.

10. Результати національних щорічних моніторингових опитувань 1994-2018 / за ред. М.А. Парашевіна. Київ : Інститут соціології НАН України, 2018. 112 c. URL: https://i-soc.com.ua/assets/files/monitoring/ dodatki2018.pdf.

11. Фоломєєв М.А. Концептуалізація політичних інновацій у сучасному українському політичному процесі. Вісник Харківського національного універcumemy імені В.Н. Каразіна. Серія «Питання політології»». Харків, 2010. № 16 (885). С. 201-207.

12. Brams S. Game Theory. URL: http://serious-science.org/game-theory-7846.

13. Della Porta D., Monticelli L. The Successes of Political Consumerism as a Social Movement. The Oxford Handbook of Political Consumerism. Oxford : Oxford University Press, 2018. Pp. 772-792.

14. Halfmann D., Amenta E. Opportunity Knocks: The Trouble with Political Opportunity and What You Can Do about It. Contention in Context: Political Opportunities and the Emergence of Protest. Palo Alto, California : Stanford University Press, 2011. Pp. 227-239. 